\title{
UJI KUALITAS PRODUK KERUPUK JAGUNG PULUT (VARIETAS LOKAL) DALAM UPAYA PENINGKATAN PENJUALAN USAHA UMKM DI KABUPATEN TOJO UNA-UNA
}

\author{
Nuranisa*, Jusriadi*, Muhammad Amiruddin*, Rosida P. Adam*
}

\begin{abstract}
ABSTRAK
Jagung adalah sumber makanan kedua setelah nasi. Penggunaan jagung untuk industri makanan sangat maju dan bervariasi untuk industri menengah dan atas seperti industri makanan ringan, minyak jagung, tepung jagung, bubur jagung, margarin, gula dan sebagainya. Namun, pada skala petani atau usaha kecil, jagung umumnya hanya dijual sebagai makanan ringan atau makanan ringan. Dalam upaya meningkatkan nilai tambah dan implementasi jagung, perlu untuk mengolah jagung menjadi produk kerupuk jagung. Penelitian ini membahas (1) Mengetahui kualitas rasa, aroma, tekstur dan kerenyahan kerupuk pulut berdasarkan jagung muda dan jagung tua, (2) Sebagai sumber informasi untuk membuat kerupuk jagung berkualitas dan (3) Penelitian ini menggunakan deskriptif metode yang membandingkan dua fakta atau lebih, dengan Metode Analisis Regresi Linier Berganda yang terdiri dari 2 pengolahan kerupuk jagung muda dan kerupuk jagung tua, uji organoleptik dilakukan di 3 desa yang lebih tinggi di Kabupaten Tojo Una-Una dan masing-masing desa terdiri dari 20 peserta uji organoleptik. Dapat dianggap 60 peserta tes organoleptik. Hasil penelitian menunjukkan bahwa ada lebih banyak kerupuk jagung daripada mereka yang tidak. Uji organoleptik kerupuk jagung yang dihasilkan adalah kerupuk jagung muda. Kerupuk jagung pada parameter kerenyahan dinyatakan sebagai nilai tertinggi 48,16\%, Warna 39,3\%, rasa 36\% dan aroma 35\%. Uji organoleptik dari tiga desa yang lebih disukai kerupuk jagung adalah Desa Padang Tumbuo.
\end{abstract}

Kata kunci: Jagung, kerupuk jagung, uji organoleptik

\section{ABSTRACT}

Corn is the second food source of food after rice. The use of corn for the food industry is highly developed and varied for the middle and upper industries such as the light food industry, corn oil, cornstarch, grits, margarine, sugar and so on. However, on a farmer or small business scale, corn is generally only sold as snacks or snacks. In an effort to increase the added value and implementation of corn, it is necessary to process corn into corn cracker products. This study discusses (1) Knowing the quality of taste, aroma, texture and crispness of pulut crackers based on young corn and old corn, (2) As a source of information for making quality corn crackers and (3)This research uses a descriptive method that compares two or more facts, with the Multiple Linear Regression Analysis Method consisting of 2 processing of young corn crackers and old corn crackers, organoleptic tests conducted in 3 higher villages in Tojo Una-Una Regency and each village consists from 20 organoleptic test participants. Can be considered 60 organoleptic test participants. The results showed that there were more corn crackers than those who didn't. Organoleptic test of corn crackers that is produced is young corn crackers. Corn crackers on crispness parameters were stated to be the highest value of $48.16 \%$, Color $39.3 \%$, taste $36 \%$ and aroma $35 \%$. Organoleptic test of the three villages which preferred corn crackers is Padang Tumbuo Village. 
Keywords: Corn, corn crackers, organoleptic tests.

\section{PENDAHULUAN}

Daerah Sulawesi Tengah masih menjadi andalan komoditas jagung hal ini dipertegas oleh Maemunah dan Lapanjang 2002, bahwa koleksi jagung ketan lokal memiliki jumlah yang banyak dan beragam serta tersebar luas di beberapa daerah dan dijadikan sebagai salah satu makanan utama, sehingga dikenal berbagai masakan jagung khas di daerah. Berdasarkan sifat patinya, jagung ketan (Waxy corn) atau disebut juga jagung pulut dimana sebagian besar patinya terdiri dari amilopektin yang dalam pemasakan menjadi lengket dan pulen sehingga jagung ketan banyak digemari untu dikonsumsi, baik dalam bentuk segar maupun produk olahannya.

Jagung merupakan bahan pangan sumber karbohidrat kedua setelah beras. Produk yang paling umum dikenal adalah jagung bakar dan jagung rebus yang diolah dari jagung muda. Biji jagung dapat diolah menjadi minyak, gula cair, cornflake, tortila, kerupuk, pati, tepung, dan berbagai macam kue termasuk makanan tradisional. Tepung jagung dapat digunakan sebagai bahan baku berbagai kue/roti, sedangkan pati jagung dapat digunakan antara lain dalam industri tekstil, untuk membuat dekstrin, bahan baku lem, sabun, dan sirup gula. Selain sebagai bahan pangan, jagung mempunyai potensi sebagai bahan baku industri makanan, minuman, kimia, farmasi dan industri lainnya

Salah satu jenis olahan jagung yang potensial untuk pengembangan industri pangan di perdesaan adalah kerupuk jagung. Keuipuk jagung telah lama dikenal, namun distribusi pemasarannya masih dalam skala lokal akibatnya kerupuk jagung kurang begitu dikenal oleh masyarakat.
Masih jarang wiraswastawan yang memanfaaa tkan jagung untuk diolah menjadi kerupuk. Umumnya jagung diolah menjadi marning, grontol, Pop Corn, tepung, dan lainnya untuk kebutuhan pakan ternak.

Kerupuk adalah produk yang dibuat dari campuran tepung beras dan bahan tambahan lainnya. Pengolahan kerupuk dengan cara digoreng sebelum disajikan. Pembuatan kerupuk secara garis besar terdiri dari persiapan bahan baku, pengadonan, pencetakan, pengukusan, pendinginan, pengirisan, pengeringan dan pengemasan. (Aviana dan Hutajulu, 2014).

Dalam upaya meningkatkan nilai tambah dan pemanfaatan jagung maka perlu dilakukan pengolahan jagung menjadi produk kerupuk jagung. Produk kerupuk jagung ini sangat tepat untuk memenuhi kebutuhan akan makanan ringan yang sehat karena kebutuhan konsumen yang semakin sadar dengan kesehatan dan sedang meluangkan perhatian yang banyak tentang jenis-jenis produk yang alami. Pengolahan kerupuk jagung yang tepat dan bahan tambahan yang tepat akan menghasilkan produk yang berkualitas sehingga perlu dilakukan penelitian tentang pembuatan kerupuk jagung menggunakan jagung pulut muda dan jagung pulut kering. Tujuan penelitian adalah

- Mengetahui kualitas rasa, aroma, tekstur dan kerenyahan kerupuk jagung pulut berbahan dasar jagung muda dan jagung tua

- Sebagai sumber informasi pembuatan kerupuk jagung yang berkualitas

- Menambah wawasan warga masyarakat khususnya bidang pengolahan cemilan.

\section{METODE PENELITIAN Waktu dan tempat}


Penelitian uji organoleptik kerupuk jagung akan di laksanakan pada bulan Maret sampai April. Tempat pelaksnaaan uji kualitas akan dilaksanakan di beberapa Desa di Kabupaten Tojo Una-Una.

\section{Alat dan Bahan}

Alat yang digunakan saat penelitian adalah kertas kusioner, polpen, dan kamera. Alat yang digunakan pengolahan kerupuk jagung adalah timbangan, baskom, spatula, ember, penggiling daging, blender, kompor gas, wajan, panci, irus, nampan, plastik bening, pipa, mistar, kemasan plastik, dan mesin press

Bahan yang digunakan adalah Jagung pipil $5 \mathrm{~kg}$, tepung beras $2 \mathrm{~kg}$, garam 1 bungkus, gula $500 \mathrm{~g}$, penyedap rasa secukupnya dan Minyak Goreng $5 \mathrm{~kg}$.

\section{Desain Penelitian}

Penelitian ini menggunakan metode deskriptif yaitu membandingkan dua gejala atau lebih, dengan Metode Analisis Regresi Linier Berganda yang terdiri atas 2 perlakuan Kerupuk jagung muda dan kerupuk jagung tua, uji organoleptik dilakukan di 3 Desa yang berbeda di Kabupaten Tojo Una-Una dan setiap Desa terdiri dari 20 peserta uji organoleptik. Sehingga terdapat 60 peserta uji organoleptik.

Teknik pengumpulan data kuantitatif metode skala metode pengumpulan data dalam penelitian dilakukan dengan menggunakan skala likert digunakan untuk mengukur sikap, pendapat dan persepsi seseorang atau kelompok orang tentang organoleptik. Dalam skala like ada dua pernyataan sikap, yaitu suka dan tidak suka pada kerupuk jagung.

\section{Pelaksanaan Penelitian}

1. Menetapkan tiga lokasi penelitian yaitu Desa Patingko, Desa Padang Tumbuo dan Desa Labuan

2. Menetapkan peserta uji kualitas produk kerupuk jagung sebanyak 15 orang di setiap Desa

3. Menetapkan waktu pelaksanaan penelitian

4. Proses Pengolahan kerupuk jagung

5. Melakukan uji kualitas produk kerupuk jagung di tiga Desa

\section{Proses Pengolahan Kerupuk Jagung}

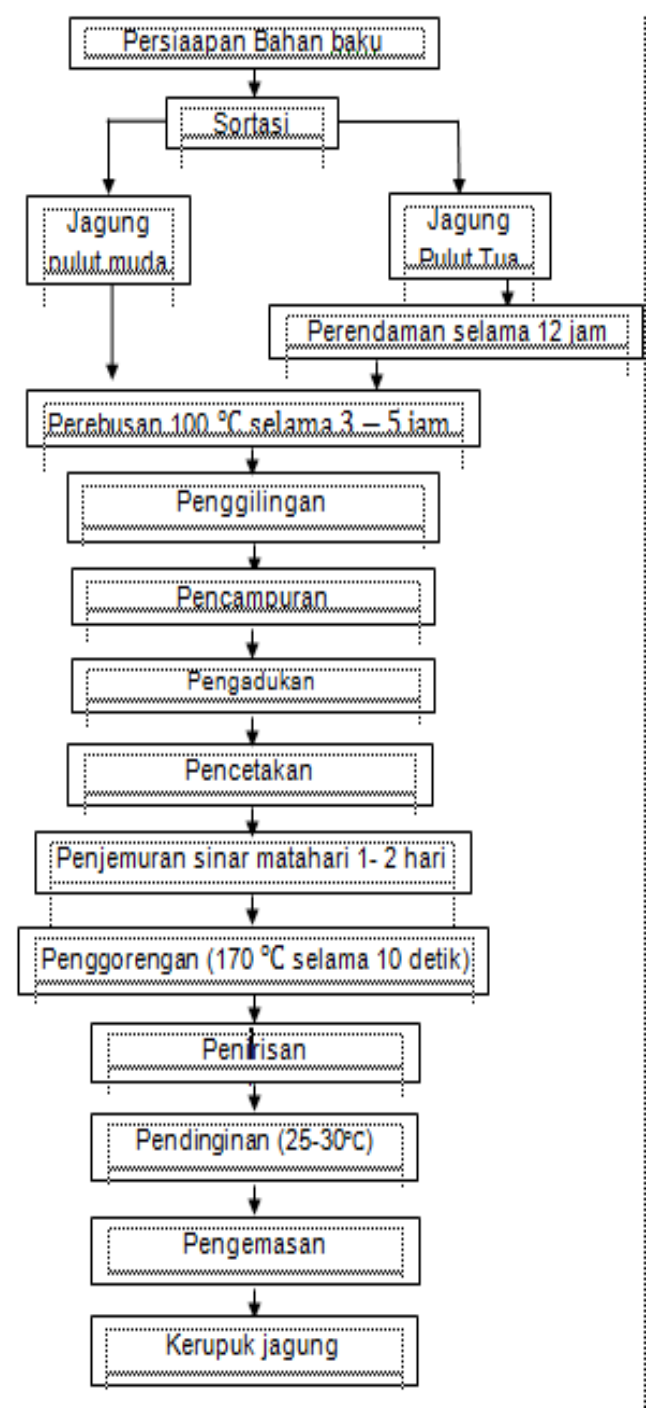

Gambar 1. Diagram Pembuatan Kerupuk Jagung

HASIL DAN PEMBAHASAN 
Uji organoleptik atau uji indera atau uji sensori merupakan cara pengujian dengan menggunakan indera manusia sebagai alat utama untuk pengukuran daya penerimaan terhadap produk. Penerimaan konsumen terhadap suatu produk pangan diawali dengan penilaiannya terhadap pengukuran, penampakan, aroma, flavor dan tekstur. Karena pada akhirnya yang dituju adalah penerimaam konsumen, maka uji organoleptik yang menggunakan panelis (pencicip yang agak telah terlatih) dianggap yang paling peka dan karenanya sering digunakan dalam menilai mutu berbagai jenis makanan untuk mengukur kesukaan penilai terhadap produk tersebut baik dari segi rasa, warna dan kerenyahan dari produk dengan menggunakan indera, selain itu metode ini disepakati sebagai metode pengujian yang praktis dalam menentukan kecepatan dan ketepatan, pengujian organoleptik juga lebih murah biayanya.

Hasil uji organoleptik terdiri atas uji ranking terhadap dua jenis produk kerupuk jagung, Pada uji rangking pemberian skor yang digunakan adalah 1 (suka) dan 0 (tidak suka). Dalam uji rangking angka nol (1) menyatakan tingkat penerimaan terendah dan angka satu menyatakan tingkat penerimaan yang tinggi terhadap produk kerupuk jagung. Penyajian dilakukan dengan mengemas masing-masing produk ke dalam kemasan plastik alumunium foil dan masing-masing kemasan diberi label. Sebelum melakukan uji hedonic, panelis diberi pengarahan untuk menilai kerupuk jagung yang disajikan dalam uji organoleptik.

Evaluasi organoleptik dapat digunakan untuk menilai adanya perubahan yang dikehendaki atau tidak dikehendaki dalam suatu produk. Dalam penelitian ini dilakukan analisis sensori guna mengetahui tingkat penerimaan organoleptic panelis terhadap kerupuk.

Uji organoleptik yang digunakan dalam penelitian ini adalah uji skoring dengan jumlah 20 panelis di tiga Desa yaitu Desa Labuan, Desa Patingko, dan Desa Padang Tumbuo. Parameter yang diujikan pada organoleptik ini meliputi warna, aroma, rasa dan kerenyahan.

\section{Rasa}

Rasa yang melibatkan panca indera lidah merupakan faktor penting dalam mengenali dan membedakan asin, asam, manis dan pahit pada produk pangan. Rasa makanan dapat dikenali dan dibedakan oleh kuncup-kuncup cecapan yang terletak pada papilla yaitu pada bagian noda merah jingga pada lidah. Atribut rasa banyak ditentukan oleh formulasi yang digunakan dan kebanyakan tidak dipengaruhi oleh pengolahan suatu produk pangan (Winarno, 1997).

Menurut DeMan (1997), pada umumnya rasa yang telah disepakati ada empat rasa yaitu manis, pahit, asam, dan asin. Kepekaan tehadap rasa terdapat pada kuncup rasa pada lidah. Hubungan antara struktur kimia suatu senyawa lebih mudah ditentukan dengan rasanya. Hasil uji organoleptik rasa dapat dilihat pada gambar 2 .

Kerupuk Jagung Muda

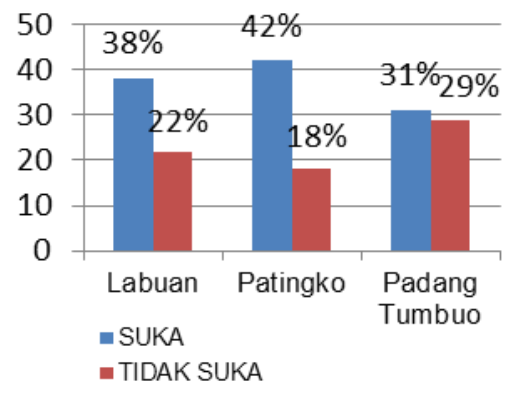




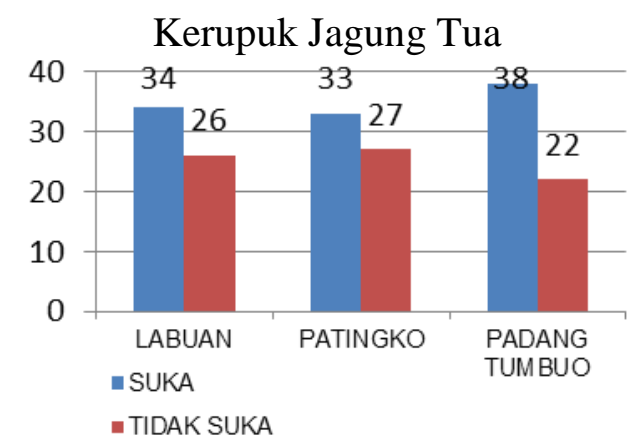

Gambar 2. Uji organoleptik Rasa kerupuk jagung muda dan kerupuk jagung tua

\section{Aroma}

Menurut Winarno, (2004) dalam Montolalu et al., (2013) aroma makanan banyak menentukan kelezatan bahan makanan tersebut. Aroma juga dapat mencirikan karakteristik dari produk tersebut sehingga melalui aroma, konsumen atau masyarakat dapat mengetahui bahan-bahan yang terkandung dalam suatu produk. Menurut Soekarto, (1985) industri makanan menganggap sangat penting melakukan uji aroma karena dengan cepat dapat memberikan hasil penilaian produksinya disukai atau tidak disukai. Aroma biasanya muncul dari bahan yang diolah karena senyawa volatile yang terkandung pada bahan pangan yang keluar melalui proses pengolahan atau perlakuan tertentu. Hasil uji organoleptik aroma dapat dilihat pada gambar 3 .

Kerupuk Jagung Muda

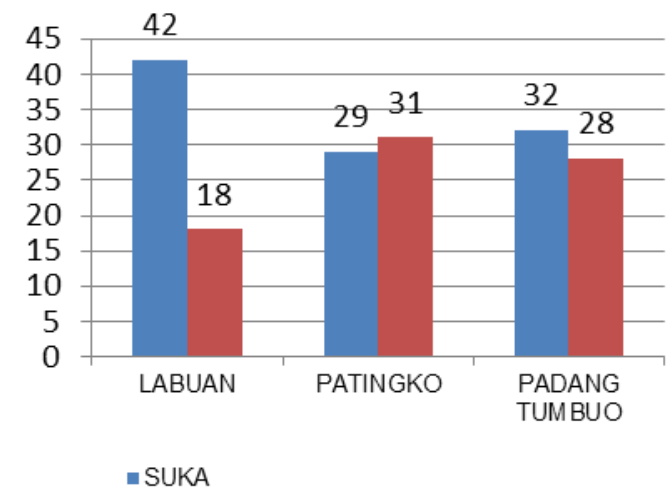

- TIDAK SUKA
Kerupuk Jagung Tua

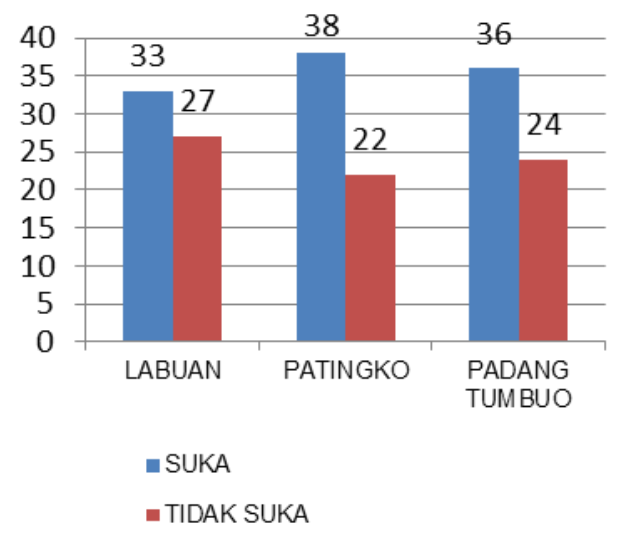

Gambar 3. Uji organoleptik aroma kerupuk jagung muda dan kerupuk jagung tua

Uji organoleptik kerupuk jagung pulut di tiga Desa pada parameter aroma menunjukan bahwa tingkat kesukaan kerupuk jagung lebih banyak dibandingkan yang tidak suka. Tingkat kesukaan tertinggi pada kerupuk jagung adalah kerupuk jagung muda sedangkan tingkat kesukaan terendah adalah kerupuk jagung tua. Aroma pada kerupuk jagung muda di Desa Labuan menunjukan tingkat kesukaan tertinggi $42 \%$, selanjutnya tingkat kesukaan kedua adalah Desa Padang Tumbuo 32\%, dan tingkat kesukaan terendah adalah Desa Patingko 29\%. Uji organoleptik kerupuk jagung tua pada aroma menunjukan bahwa Desa yang memiliki tingkat kesukaan tertinggi adalah Desa Patingko 38\%, selanjutnya Desa kedua yang memiliki tingkat kesukaan adalah Padang Tumbuo 36\% dan Desa yang memiliki tingkat kesukaan terendah adalah Labuan $33 \%$.

\section{Kerenyahan}

Kerenyahan merupakan antribut yang penting dalam makanan renyah seperti 
kerupuk. Setiap makanan memiliki tekstur serta tingkat kesukaan panelis yang beragam. Sehingga dilakukan uji sensori guna mengetahui tingkat kesukaan panelis terhadap tekstur dari kerupuk. Hasil uji organoleptik kerenyahan kerupuk jagung dapat dilihat pada gambar 4.

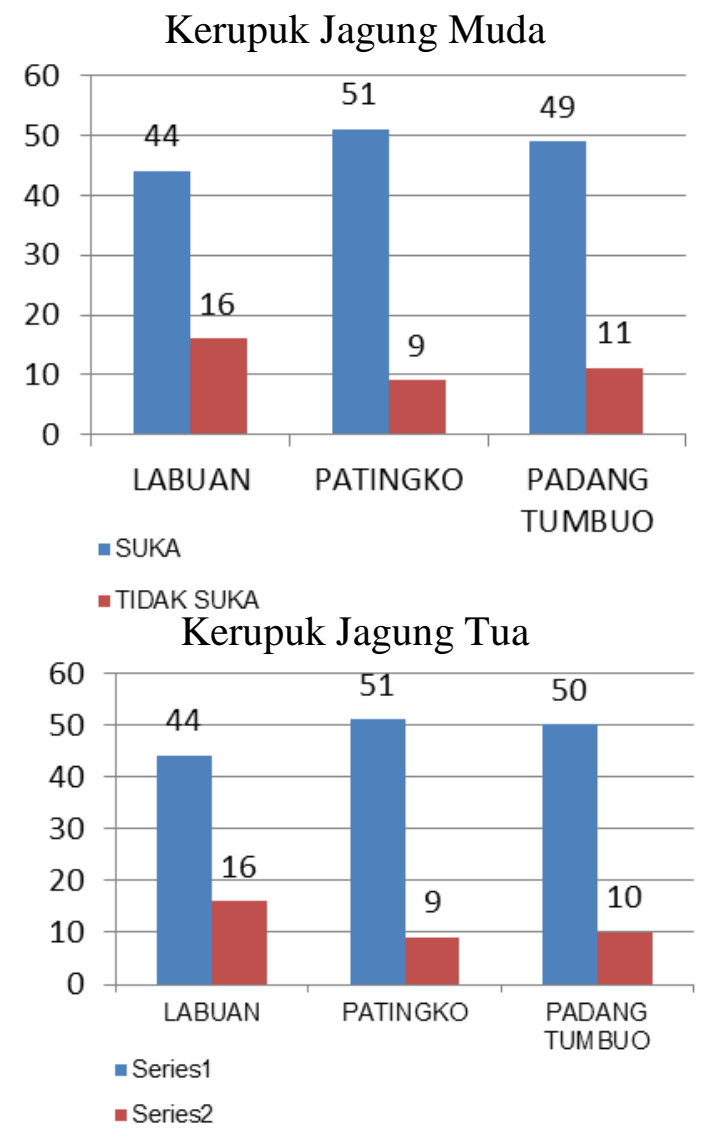

Gambar 4. Uji organoleptik kerenyahan kerupuk jagung muda dan kerupuk jagung tua

Uji organoleptik kerupuk jagung pulut di tiga Desa pada parameter kerenyahan menunjukan bahwa tingkat kesukaan kerupuk jagung lebih banyak dibandingkan yang tidak suka. Tingkat kesukaan tertinggi pada kerupuk jagung adalah kerupuk jagung muda sedangkan tingkat kesukaan terendah adalah kerupuk jagung tua. Kerenyahan kerupuk jagung muda yang menunjukan tingkat kesukaan terttinggi adalah Desa Patingko $51 \%$, selanjutnya Desa kedua adalah Desa
Padang Tumbuo 49\% dan tinkat kesukaan terendah adalah Desa Labuan. Uji organoleptik kerupuk jagung tua menunjukan bahwa Desa yang memiliki tingkat kesukaan tertinggi adalah Desa Patingko 51\%, selanjutnya Desa yang memiliki tingkat kesukaan kedua adalah 50\% dan Desa yang memiliki tingkat kesukaan terendah adalah Desa Labuan.

Hal ini karena penggunaan tepung tapioka menghasilkan kerupuk yang dapat mengembang. Keunggulan tepung tapioka dalam pembuatan kerupuk adalah mempengaruhi kerenyahan kerupuk. Koswara (2009) menyatakan bahwa penggunaan tepung tapioka dalam proporsi yang lebih besar daripada tepung terigu dapat membentuk struktur adonan yang kuat sehingga kerupuk menjadi mengembang.

Menurut Zulviani (1992) dalam Istanti (2005), pada dasarnya kerupuk dengan kandungan amilopektin yang lebih tinggi memiliki pengembangan yang tinggi karena pada saat pemanasan terjadi proses gelatinisasi dan terbentuk struktur yang elastis, yang kemudian mengembang pada tahap penggorengan. Sesuai dengan pendapat Wahyono dan Marzuki (2010), proporsi penambahan tepung tapioka dan bahan utama yang seimbang dapat mengembangkan kerupuk saat digoreng. Semakin mengembang kerupuk semakin renyah dan disukai panelis.

Menurut Kusumaningrum (2009), pengembangan kerupuk setelah digoreng dapat disebabkan oleh terbentuknya ronggarongga udara. Air terikat pada kerupuk ampas susu kedelai dan menguap jika telah digoreng pada suhu tinggi. Tekanan uap yang dihasilkan akan mendesak gel pati, sehingga terbentuk produk yang mengembang. 
Kandungan pati menurut Koswara
(2009) menyatakan kandungan pati yang digunakan pada kerupuk maka akan semakin renyah pula kerupuk yang dihasilkan. Tepung tapioka memiliki kadar amilopektin yang tinggi sehingga akan meningkatkan kerenhyahan kerupuk. semakin banyak proporsi tapioka yang dipakai maka akan semakin mengembang kerupuk yang dihasilkan

Pada dasarnya komponen utama yang mendominasi dalam pembuatan kerupuk adalah pati. Pati mempunyai dua komponen utama yaitu amilosa (fraksi larut) dan amilopektin (fraksi tidak larut). Amilopektin merupakan salah satu komponen pati yang mempengaruhi daya kembang kerupuk. Menurut Zulfani (1992), amilopektin berfungsi sebagai pemberi sifat renyah pada kerupuk. Kerupuk dengan kandungan amilopektin tinggi memiliki daya kembang yang tinggi dan sifat keerenyahan yang tinggi pula. Hali ini dikarenakan dalam proses pemanasan akan terjadi prosses gelatinisasi pati dan akan terbentuk struktur yang elastis yang dimungkinkan untuk dapat mengembangkan volume krupuk pada proses pemanggangan atau pemangangan sehingga memiliki kerenyahan yang tinggi pula (Rosiani et al., 2015).

Saat pemanasan akan menyebabkan proses gelatinisasi dimana granula pati menyerap air dan terjadi pembengkakan. Selanjutnya granula ini akan pecah sehingga air yang masuk dalam butir-butir pati tidak dapat bergerak bebas. Hal ini berakibat pada tekstur produk menjadi padat dan kompak antar partikel. (Zulfahmi et al., 2014).

\section{Warna}

Faktor warna sangat menentukan penilaian bahan pangan sebelum faktor-faktor lain dipertimbangkan secara visual. Penerimaan warna suatu bahan berbeda-beda tergantung dari faktor alam, geografis, dan aspek sosial masyarakat penerima. Warna juga dapat digunakan sebagai indikator kesegaran atau kematangan (Winarno, 1992). Hasil uji organoleptik warna dapat dlihat pada gambar 5.
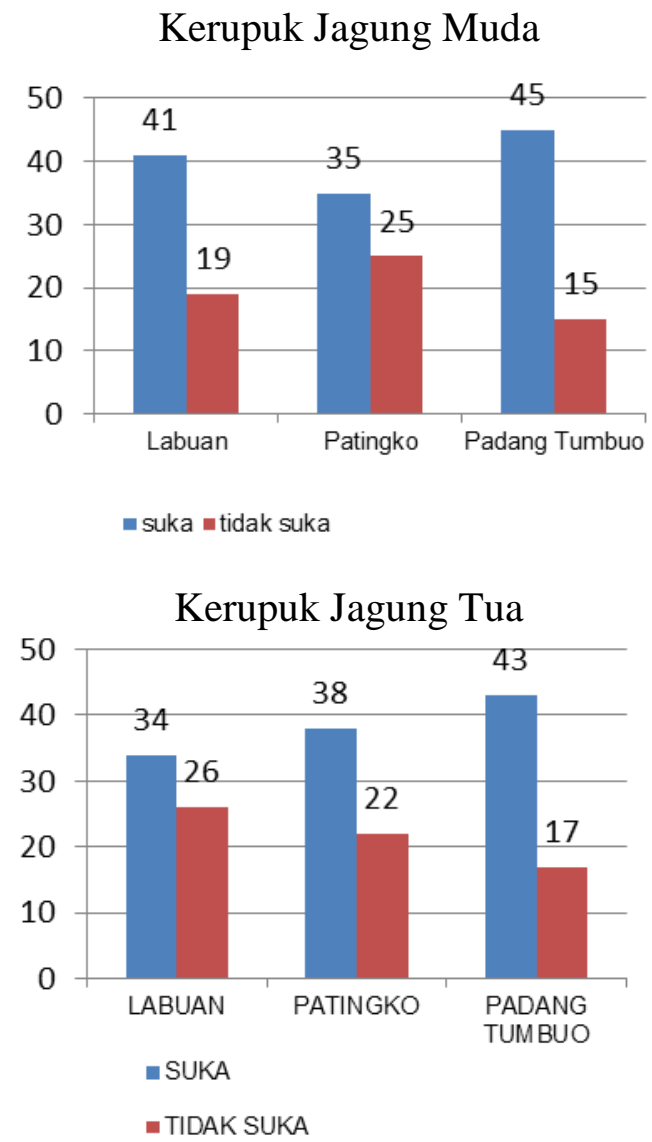

Gambar 5. Uji organoleptik warna kerupuk jagung muda dan kerupuk jagung tua

Uji organoleptik kerupuk jagung pulut di tiga Desa pada parameter aroma menunjukan bahwa tingkat kesukaan kerupuk jagung lebih banyak dibandingkan yang tidak suka. Tingkat kesukaan tertinggi pada kerupuk jagung adalah kerupuk jagung muda sedangkan tingkat kesukaan terendah adalah kerupuk jagung tua. Uji organoleptik Warna kerupuk jagung muda menunjukan bahwa Desa yang 
memiliki tingkat kesukaan tertinggi adalah Desa Padang Tumbuo 45\%, selanjutnya Desa yang memiliki tingkat kesukaan kedua adalah Desa Labuan $41 \%$ dan Desa yang memiliki tingkat kesukaan terendah adalah Desa Patingko 35\%. Uji Organoleptik warna kerupuk jagung tua menunjukan bahwa Desa yang memiliki tingkat kesukaan tertinggi adalah $43 \%$, selanjutnya Desa yang memiliki tingkat kesukaan kedua adalah Desa Patingko $38 \%$ dan Desa yang memiliki tingkat kesukaan terendah adalah Desa Labuan 34\%.

Menurut Winarno (1997), warna dalam bahan dapat berasal dari pigmen alami bahan pangan itu sendiri, reaksi karamelisasi, reaksi Maillard, reaksi senyawa organik dengan udara, dan penambahan zat warna baik alami maupun sintetik (Rosiani,et al., 2015).

Perubahan warna kerupuk yang diakibatkan adanya reaksi pencoklatan non enzimatis dapat terjadi dikarenakan kandungan gizi kerupuk yang banyak mengandung karbohidrat dan sedikit protein, sehingga gula pereduksi akan bereaksi dengan gugus amina primer dari protein yang menghasilkan pigmen melanoidin yang dapat mengakibatkan warna coklat pada kerupuk (Ketaren, 1986). Menurut Martins (2001), reaksi Maillard terkait dengan aroma, rasa dan warna terutama dalam makanan seperti proses pemanggangan biji kopi, roti, sereal dan pemasakan daging. Terjadinya reaksi Maillard dalam penelitian ini yaitu ketika kerupuk mengalami proses pengukusan dan pemangangan (Rosiani et al., 2015).

Menurut Suhardi (2006) dalam Rusman et al., (2016), kerupuk dengan pencampuran tepung tapioka mempunyai mutu yang lebih baik daripada tanpa campuran dilihat dari segi warna, aroma, tekstur, dan rasa.
1.

ji organoleptik kerupuk jagung lebih banyak yang suka dibandingkan yang tidak suka

2.

ji organoleptik kerupuk jagung yang banyak disukai adalah kerupuk jagung muda

3.

erupuk jagung pada parameter kerenyahan menyatakan nilai tertinggi $48.16 \%$, Warna $39.3 \%$, rasa $36 \%$ dan aroma $35 \%$

4.

ji organoleptik tiga Desa yang lebih banyak menyukai kerupuk jagung adalah Desa Padang Tumbuo

\section{Saran}

Sebaiknya penelitian selanjutnya adalah melakukan analisa mutu kimia dan mutu fisik kerupuk jagung.

\section{DAFTAR PUSTAKA}

Albanjar, F. V. 2017. Analisis Kesesuaian Persyaratan Produksi Kerupuk Jagung Menuju Standar Nasional (Kajian Pada Ukm Mawar Merah, Luwu Utara). Program Studi Ilmu dan Teknologi Pangan. Universitas Hasanuddin. Makassar

Aviana, T., dan Hutajulu, T.F., 2014. Karakteristik Kerupuk dari Tepung Jagung Pulut (Zea mays L). Warta IHP, 31 (2), Hal. 70-76

DeMan. 1997. Kimia Makanan Edisi Kedua. Penerbit ITB Bandung. Bandung.

Istanti. 2006. Pengaruh Lama Penyimpanan terhadap Sifat Fisik dan Sensori Kerupuk Ikan Sapusapu (Hyposarcus pardalis) yang Dikeringkan dengan Menggunakan Sinar Matahari. Skripsi. Fakultas Perikanan dan Ilmu Kelautan. Institut Pertanian Bogor. Bogor.

\section{Kesimpulan}


Ketaren, S. 1986. Pengantar Teknologi Minyak dan Lemak Pangan. Penerbit UI Press. Jakarta.

Koswara, S., 2009. Pengolahan Aneka Kerupuk. Ebookpangan.com

Kusumaningrum, I. 2009. Analisa Faktor Daya Kembang dan Daya Serap Kerupuk Rumput Laut Pada Variasi Proporsi Rumput Laut (Eucheuma cootonii). Jurnal Teknik Pertanian Univ Mulawarman vol. 4 (2).

Maemunah dan I. Lapanjang, 2002. Pengaruh Takaran dan Waktu Pemberian Kalium Terhadap Pertumbuhan dan Produksi Jagung. Jurnal Agroland vol. 9 no. 1 (Maret).

Martins, S.I.F.S., Jongen, M.F.W., van Boekel, M.A.J.S. 2001. A review of Maillard reaction in food and implications to kinetic modeling. Trends in Food Science and Technology, vol. 11 pp: 364-373.

Montolalu S, N. Lontaan, S. Sakul, A. Dp. Mirah. 2013. Sifat Fisiko-Kimia dan Mutu Organoleptik Bakso Broiler dengan Menggunakan Tepung Ubi Jalar (Ipomoea batatas L). Jurnal Zootek vol. 32 (5), Fakultas Peternakan Universitas Sam Ratulangi, Manado.

Rusman, A.A.R., Kadirman, dan Caronge, M.W. 2016. Pengembangan Produk Kerupuk Udang Melalui Substitusi Tepung Ubi Jalar Ungu (Ipomoea Batatas Lam) dengan Variasi Lama Penggorengan. Alumni Program Studi Pendidikan Teknologi Pertanian 2 dan 3 Dosen PTP FT UNM. vol. 2, hal. 135-148.

Rosiani, N., Basito, Widowati, E. 2015. Kajian Karakteristik Sensoris Fisik Dan Kimia Kerupuk Fortifikasi Daging Lidah Buaya (Aloe Vera)
Dengan Metode Pemanggangan Menggunakan Microwave (Study of Sensory Characteristics, Physical, And Chemical Properties of Fortified Crackers with Aloe Vera Using Microwave Roasting Methods). Program Studi Ilmu dan Teknologi Pangan. Jurnal Teknologi Hasil Pertanian, Vol. VIII, No. 2.

Soekarto, S.T. 1985. Penilaian Organoleptik (untuk Industri Pangan dan Hasil Pertanian). Penerbit Bharata Karya Aksara. Jakarta.

Winarno, F.G. 1992. Kimia Pangan dan Gizi. Peneribit Gramedia Pustaka Utama. Jakarta.

Winarno, F. G. 1997. Kimia Pangan dan Gizi. Penerbit Gramedia Pustaka Utama. Jakarta.

Wahyono, R. dan Marzuki. 2010. Pembuatan Aneka Kerupuk. Penerbit Penebar Swadaya. Jakarta.

Zulfahmi, A.N., dan Swastawati, F., dan Romadhon. 2014. Pemanfaatan Dagingikan Tenggiri (Scomberomorus Commersoni) Dengan Konsentrasi Yang Berbedapada Pembuatan Kerupuk Ikan (The Use of Different Concentration of Spanish Mackerel Flesh (Scomberomorus commersoni) in the Fish Crackers Production). Program Studi Teknologi Hasil Perikanan, Jurusan Perikanan Fakultas Perikanan dan Ilmu Kelautan, Universitas Diponegoro Jurnal Pengolahan dan Bioteknologi Hasil Perikanan Vol. 3, No. 4, Hal. 133-139.

Zulfani, R. 1992. Pengaruh Berbagai Tingkat Suhu Penggorengan Terhadap Pola Pengembangan Kerupuk Sagu Goreng. Jurusan Teknologi Pangandan Gizi, Institut Pertanian Bogor. 
*Dosen SKU Universitas Tadulako

(Email: aanuranisa@gmail.com) 